\title{
Design of a Technical-Artisanal Dike for Surface Water Storage and Artificial Recharge of the Manglaralto Coastal Aquifer. Santa Elena Parish, Ecuador
}

\author{
Paúl Carrión-Mero ${ }^{1,2^{*}}$, Fernando Morante-Carballo ${ }^{1,3,4}$, Josué Briones-Bitar ${ }^{1,2}$, Paúl Herrera-Borja ${ }^{5}$, Miguel Chávez- \\ Moncayo $^{6}$, Juan Arévalo-Ochoa ${ }^{2}$ \\ ${ }^{1}$ ESPOL Polytechnic University, Centro de Investigaciones y Proyectos Aplicados a las Ciencias de la Tierra (CIPAT), \\ Campus Gustavo Galindo Km 30.5 Vía Perimetral, P.O. Box 09-01-5863, Guayaquil, Ecuador \\ ${ }^{2}$ ESPOL Polytechnic University, Facultad de Ingeniería Ciencias de la Tierra (FICT), Campus Gustavo Galindo Km 30.5 Vía \\ Perimetral, P.O. Box 09-01-5863, Guayaquil, Ecuador \\ ${ }^{3}$ ESPOL Polytechnic University, Facultad de Ciencias Naturales y Matemáticas (FCNM), Campus Gustavo Galindo Km 30.5 \\ Vía Perimetral, P.O. Box 09-01-5863, Guayaquil, Ecuador \\ ${ }_{4}^{4}$ ESPOL Polytechnic University, Geo-recursos y Aplicaciones (GIGA), Campus Gustavo Galindo Km 30.5 Vía Perimetral, \\ P.O. Box 09-01-5863, Guayaquil, Ecuador \\ ${ }^{5}$ Junta Administradora Regional de Agua Potable de Manglaralto, JAAPMAN, Manglaralto 241754, Ecuador \\ ${ }^{6}$ Independent Consultant, Expert in Geotechnics and Geology, Guayaquil 090101, Ecuador
}

Corresponding Author Email: pcarrion@espol.edu.ec

https://doi.org/10.18280/ijsdp.160312

Received: 25 March 2021

Accepted: 29 May 2021

\section{Keywords:}

shallow aquifer, ancestral knowledge, artificial recharge, tape

\begin{abstract}
Manglaralto parish communities are supplied with drinking water extracted from shallow aquifers (associated with alluvial terraces) recharged by seasonal rivers. The companies responsible for extracting and distributing water are the Manglaralto Regional Drinking Water Administration Board (JAAPMAN, for its acronym in Spanish) and Olon Regional Board of Drinking Water (JRAPO, for its acronym in Spanish). However, due to population growth and tourism (floating population) of Manglaralto parish, water demand has increased. This has meant that, during the dry season, the water stored in these underground reservoirs is not enough to meet the growing demand. The case study presented is that of the Manglaralto community. The aim is to design, in a technical way, an artisanal dyke (tape) by performing geological-geotechnical studies that allow optimal surface storage and artificial recharge of aquifers for the provision of water to communities. The methodology is as follows: i) Analysis of the technical starting information, ii) Recognition of the study site and the choice of sampling sites, iii) Conducting laboratory tests and analysis of information obtained in the field, and iv) Technical design of the tape. According to laboratory results and the field data analysis, the design of a spillway dyke equipped with a dentellon was defined, which acts as a screen to block the subsurface flow. The rescue of ancestral knowledge, used as a solution to current problems in this coastal community, allows storing a volume of $4,641.88 \mathrm{~m}^{3}$ and an artificial recharge of $15 \%$, with low costs and great social acceptance.
\end{abstract}

\section{INTRODUCTION}

Water is an essential element for a country's sustainable development as it plays an essential role in economic, social and human development $[1,2]$. After thousands of years of human development in which water has been an abundant resource in most areas, the situation is now changing abruptly. Particularly in arid regions of the world, water scarcity has become the biggest threat to food security, human health and natural ecosystems $[3,4]$.

In order to achieve accessibility of water, the United Nations has proposed goals to achieve this objective, among which is "Significantly increase the efficient use of water resources in all sectors and ensure the sustainability of freshwater extraction and supply to address water scarcity and significantly reduce the number of people suffering from water shortages" [5]. To achieve water supply in some towns worldwide, people have used the extraction of water from aquifers [6]. According to the International Atomic Energy Agency (IAEA), underground water is the largest drinking water source for humans. This represents $30.1 \%$ of the total fresh water in the world [7,8].

The availability of freshwater resources is a challenge for many communities, becoming a scarce good that limits social and economic development [9-11]. Ironically, low households in developing countries spend a higher proportion of their income on water than in industrialised countries [12]. The outlook on the supply and renewal of water in the world is every day worse. This is because freshwater is not distributed equitably globally, nor the same quantity in the seasons or from one year to another $[2,13]$. While the scarcity of freshwater resources already limits development and social well-being in many countries [10, 14-16], expected world population growth in the coming decades, coupled with growing economic prosperity, will increase water demand and exacerbate these problems $[17,18]$. Therefore, it is essential to 
consider an integrality in water management to counteract the its lack [19, 20]. The two methods, proposed by Sixt et al. [19], Chica and Reyes [20], to manage water resources are increased supply (e.g. water storage by dike/dams, artificial recharge of aquifers, desalination of seawater or seeding and harvesting of water), and reduction of losses and waste (e.g. control of evaporation, more efficient industrial processes in the use of water, control of losses and waste in large cities).

In Ecuador, based on the National Plan for Good Living 2013-2017 (PNBV, for its acronym in Spanish), it was monitored that " $83 \%$ of households have access to water through the public network" (goal 3.11.) [21]. The provinces with the highest water coverage are Pichincha, Santa Elena and El Oro. Santa Elena's province has $90.3 \%$ coverage by the public network $[22,23]$. However, certain towns north of Santa Elena, such as Manglaralto and Olon, do not benefit from this service $[4,24]$. Due to this, they have created water management boards (such as JAAPMAN and JRAPO), which have managed to supply the parish population through aquifers' exploitation. More than 30,000 people are supplied with this vital liquid by extracting water from wells located around the aquifers $[25,26]$.

However, the supply through aquifers also has its limitations, since population growth, lack of rain and increased tourism has generated a considerable water deficit. This leads to a shortage of water for the parish because the aquifer does not recharge quickly enough in the rainy season [20, 27]. Anciently, artisanal dikes (tapes) have been made in rivers around the world. Such is the case of the Miraflores district in Peru (built during pre-Inca times), where they have helped retain water, thus causing more significant infiltration of water into the aquifers and thus favouring their recharge [28, 29].

Among the strategies to try to solve the water shortage during the dry seasons in the community of Manglaralto is the construction of tapes, which help retain water in various sectors of the river, thus contributing to the recharge of the aquifer [26]. However, the artisanal construction of these tapes is not durable since, according to the water capacity in the river's flood, it causes their collapse, having been used in their sound stage.

Given the conditions and the construction of artisanal tapes, built through community work and materials from the river, the community considered the construction of a technicalartisan tape, that is, to implement its construction with reinforced concrete. With this, the question arises: Is it possible that the design of a technical-artisan dike, built with the same ancestral characteristics but using concrete, is viable and allows the accumulation of water in it, helping to infiltrate a more significant amount of water into the aquifer and therefore solve the water needs of the Manglaralto population?

That is why the following objective is proposed: to design an artisanal dike (tape) in a technical way by carrying out topographic and geotechnical studies and laboratory tests, which allow optimal surface storage and artificial recharge the aquifers for the water provision to the Maglaralto community.

\section{STUDY AREA}

The study area in which this research is carried out is in the Manglaralto commune located in the same name's parish. Located northwest of the Santa Elena province, in the coastal region of Ecuador [30, 31]. The Manglaralto parish has an area of $497 \mathrm{~km}^{2}$, bordered to the north and east by the province of Manabí, south by the Colonche parish and the west by the Pacific Ocean shown in Figure 1.

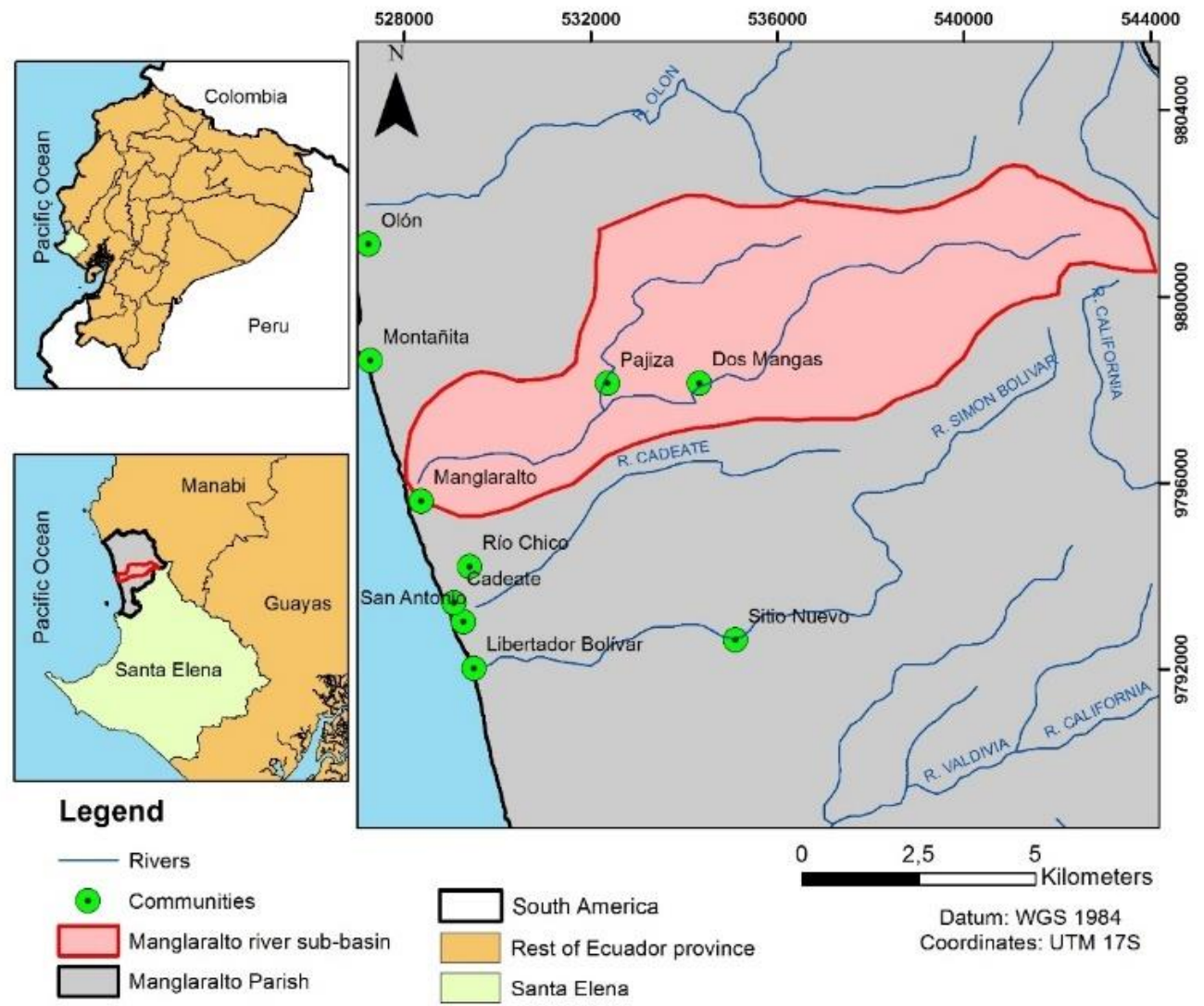

Figure 1. Parish Manglaralto community location. (Source: [32, 33]) 
The parish is located in the Manglaralto and Valdivia rivers' basins, with a basin head located in the hills of San Martin, La Culebra and La Cascada. The mountainous part of the parish is formed by the hills of Los Araujos, El Gallo, Culebra, San Martin, Colonche Los Lobos and the Olón Mountains with elevations ranging from 300 to 750 meters [26, 34].

The Manglaralto, Cadeate and Simón Bolívar rivers in the Manglaralto basin have recent alluvial deposits formed mainly of gravel and sand. The gravels present a variable classification along with the thickness of the layers and, also, they have a sandy matrix which makes them ideal for forming an aquifer. The geological formations that make up the Manglaralto River sub-basin are sedimentary and volcanosedimentary rocks with alluvial deposits found in flat reliefs bordered by elevations that exceed 100 meters in height [3537].

The Manglaralto aquifer has a surface area of approximately $5.08 \mathrm{~km}^{2}$ and the Manglaralto river basin, which feeds it, is $132.38 \mathrm{~km}^{2}$ long. Manglaralto's climate is semi-arid, with an average annual temperature in 2017 of $27.3^{\circ} \mathrm{C}$ and an approximate rainfall of $256.1 \mathrm{~mm}$ and evapotranspiration of almost $1000 \mathrm{~mm}$ [38]. In the parish, JAAPMAN has 12 active wells for the supply of 7 communes in the parish of Manglaralto: Montañita, Nueva Montañita, Manglaralto, Río Chico, Cadeate, San Antonio and Libertador Bolívar.

\section{METHODOLOGY}

The methodology used for the development of this research consisted of three stages, detailed in Figure 2.

\subsection{Recognition of the study site}

During the visit to the study site, which involved the riverbank, potential sites for constructing a dike (tape) were observed. These were selected for their characteristics, such as their geometry, terrain morphology, possible reservoir area, and the existence or not of an aquifer, according to studies by $[26,36]$. They were identified and located near water wells, the reservoir area, neck, and sectors where the river's drainage contributes more water. At the end of this, the most suitable site for the design and construction of the technical tape (reinforced concrete) was selected.

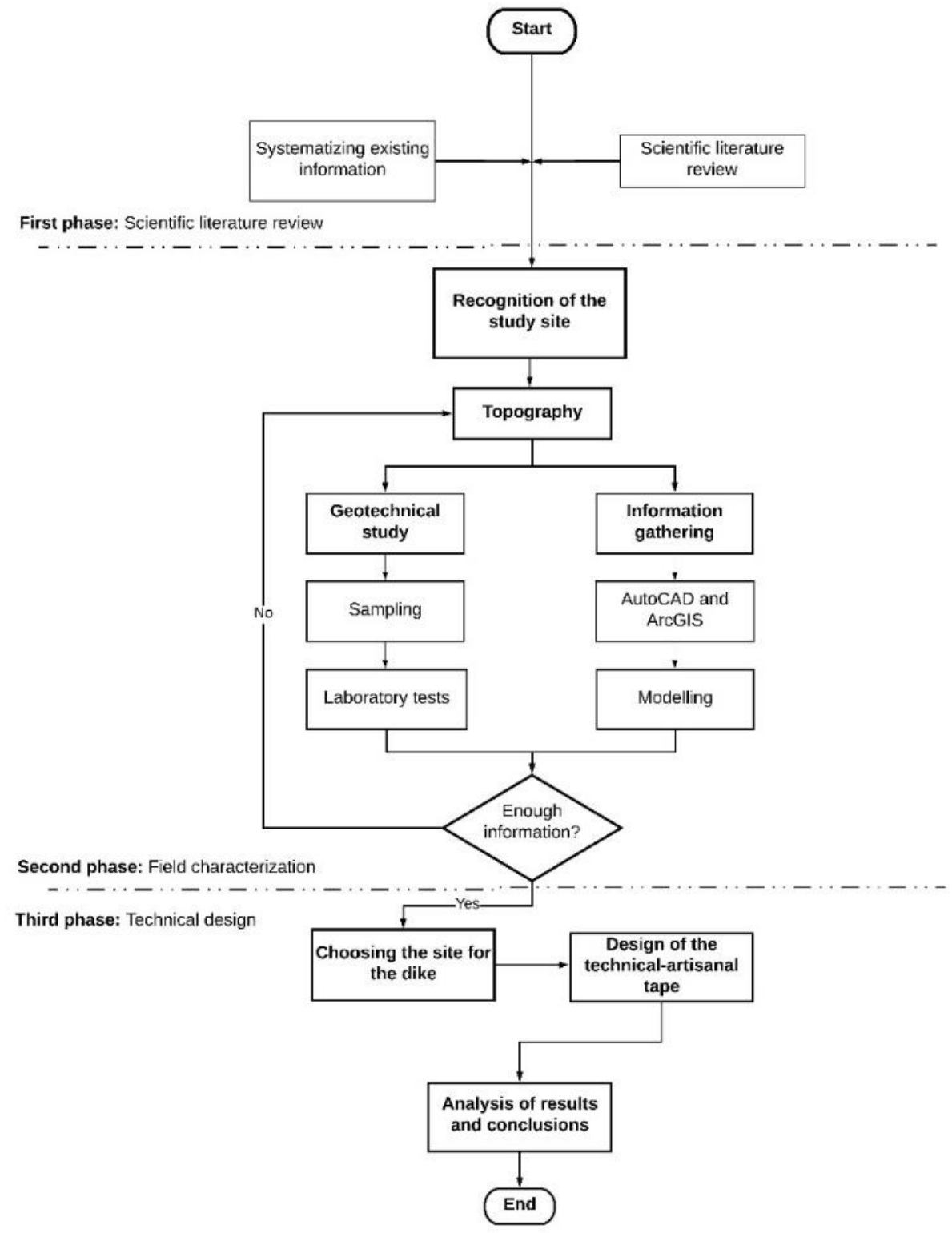

Figure 2. Flowchart of the research methodology 
The topographic study was carried out on the entire reservoir area of the chosen site to find the ideal area that maximises storage efficiency and minimises construction cost. Thanks to the studies of $[32,36]$ several factors have been analysed in the sub-basin of the Manglaralto river, such as geomorphology (slopes and relief), geology-hydrogeology, and considering the river narrowing and course. Placing the dike in a narrowing of the river guarantees a maximum of water storage (because the river widens upstream) and a minimum construction cost (because the dike is less wide in a narrowing, which translates into less material use).

The topography was carried out with differential GPS equipment. In the office, the field data obtained in specialised software, such as AutoCAD Civil 3D and ArcGIS, were entered. The possible volume of water that it could store was also estimated.

\subsection{Geotechnical characterisation}

For the dike (tape) design, it was necessary to know the soil characteristics on which it will be built. Therefore, soil samples were taken at strategic points, according to terrain's morphology, such as the sides of the slopes and the reservoir area. With this, a better representation of the soil on which the dike (tape) will be built was obtained.

For the characterisation of the soil samples, tests of granulometry, Atterberg limits [38], Triaxial [39], Los Angeles abrasion [40] and resistance to compression were performed. All tests were carried out in a laboratory specialised in soil mechanics. For the granulometry, Atterberg limits and triaxial tests, soil samples were taken from each face of the slope, for which the ground was first cleared. Then, with the help of a Shelby tube, soil samples were cored. The material's soil class, its plasticity, cohesion, and internal friction angle were known with these tests. With these results, the dike's embedment in field was designed. Los Angeles abrasion trial's purpose was to determine if the material located at the bottom of the river or the banks could be used or not as a construction material. If the value is less than $40 \%$ in the Los
Angeles Abrasion test, a concrete cylinder was made to test its resistance to compression later.

\subsection{Design of the technical-artisanal dike}

In this third phase of the methodology, the design and model of the dike was elaborated, always with the objective and purpose of maximising efficiency, minimising costs and prolonging its useful life. The results obtained from the geotechnical tests carried out on the samples obtained in the area chosen for the dike were analysed. The geometric characteristics and the most suitable materials to have and use in the dike were defined with these results. A detail of the dike design and a diagram of the proposed dike in the study sector are presented. Additionally, a referential budget calculation of the cost of this civil work is presented.

\section{RESULTS}

\subsection{Choosing the site for the dike (tape)}

The chosen site is located in the Manglaralto River subbasin, with coordinates UTM (17S) 529564 E; 9796588 S (see Figure 3). This site was chosen thanks to the data provided by $[32,36]$, which indicate it as a geologically strategic sector for creating a dike. The factors considered for determining the location of the dike were: geomorphology, hydrogeology, tectonics of the study site, proximity to water wells, and distance to the coastline. With this, the favourable conditions of the subsoil that this place presents for the storage, recharge and infiltration of water to the existing aquifer in the sector is guaranteed. Thanks to the infiltration and recharge of water to the aquifer, it is possible to reduce saline intrusion in these wells near the coastline.

After carrying out the data collection for the terrain topography, we proceeded with their analysis. The digital model can be seen in Figure 4. Two critical parameters for the dike design were determined: the dike geometry and the water volume retained in the reservoir.
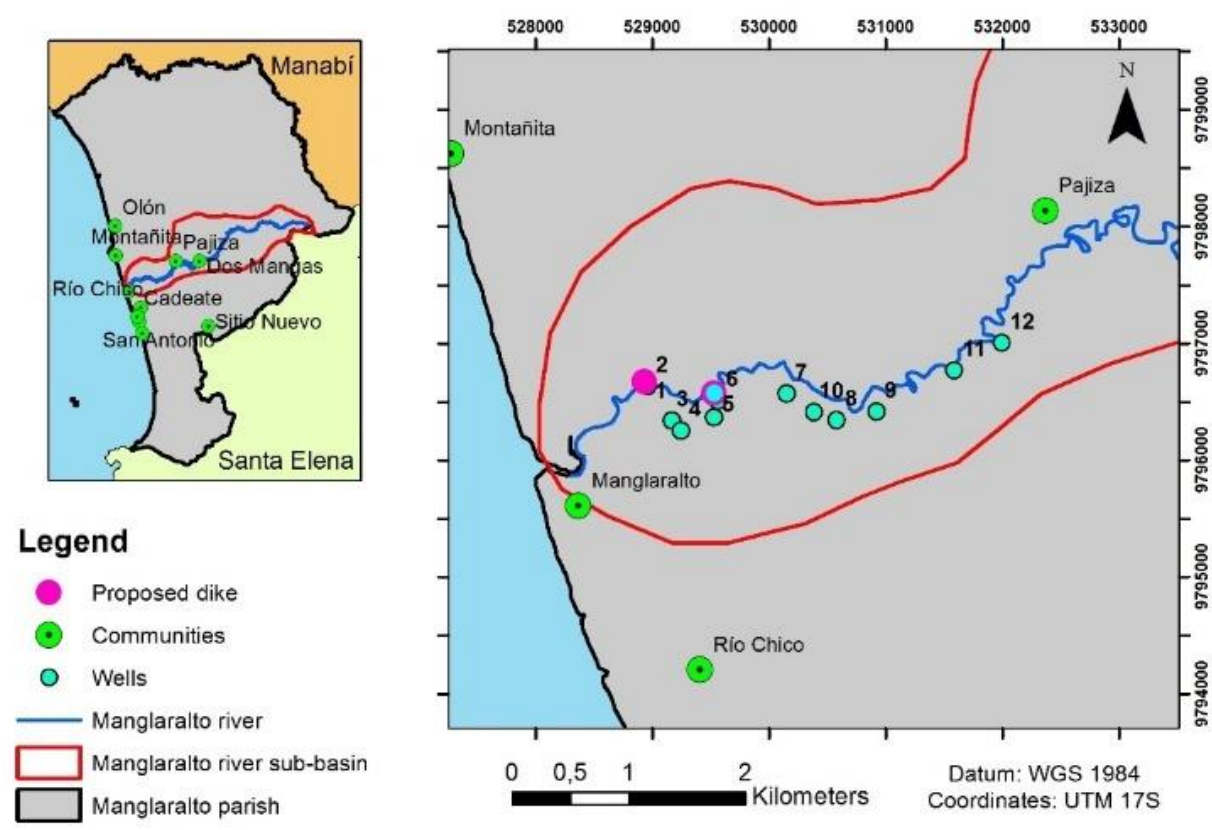

Figure 3. Dike (tape) location map 




Figure 4. Modelling the area of interest. (Source: [41])

\subsubsection{Dike geometry and volume of water retained}

It must be as narrow as possible for economic reasons, and it cannot exceed the reservoir's neck level so that the water does not escape from its sides. Thus, the estimated height was 3 meters, the same as that calculated by subtracting the highest elevation from the lowest elevation on both sides of the neck. The length was calculated so that the minimum distance reached the highest elevation that the riverbed would reach on both sides. This length is $15.45 \mathrm{~m}$ (not counting embedment of the dike).

The water volume calculation was carried out considering the reservoir as a closed reservoir using contour lines and the river level's average height, resulting in $4641.88 \mathrm{~m}^{3}$.

\subsection{Geotechnical characterisation}

Samples were taken at 5 points: the two sides of the foundation (on the slopes) and the rest in the reservoir area (in the river, at a depth of $2 \mathrm{~m}$ ). Table 1 shows the coordinates where the samples were taken. The samples were taken on the slopes (on the banks of the river) help us to design the embedment of the dike and its stability correctly. While the samples were taken along the riverbed help us know the water storage capacity and its infiltration-recharge to the aquifer.

Table 1. Location and tests performed on each sample

\begin{tabular}{c|c|c|c|c}
\hline \multirow{2}{*}{ Sample } & \multicolumn{2}{|c|}{ Coordinates } & Test & Description \\
\cline { 2 - 3 } P1 & 529.558 & $9^{\prime} 796.592$ & $\begin{array}{c}\text { Granulometry, } \\
\text { Atterberg } \\
\text { limits, Triaxial }\end{array}$ & Left slope \\
\hline P2 & 529.564 & $9 ' 796.580$ & $\begin{array}{c}\text { Granulometry, } \\
\text { Atterberg } \\
\text { limits, Triaxial }\end{array}$ & Right slope \\
\hline P3 & 529.529 & $9 ' 796.577$ & $\begin{array}{c}\text { Granulometry, } \\
\text { Atterberg } \\
\text { limits, } \\
\text { Triaxial, Los } \\
\text { Angeles } \\
\text { abrasion }\end{array}$ & $\begin{array}{c}\text { Excavation } \\
\text { in river }\end{array}$ \\
\hline P4 & 529.545 & $9^{\prime} 796.581$ & $\begin{array}{c}\text { Los Angeles } \\
\text { abrasion }\end{array}$ & $\begin{array}{c}\text { Excavation } \\
\text { in river }\end{array}$ \\
\hline P5 & 529.569 & $9^{\prime} 796.589$ & $\begin{array}{c}\text { Los Angeles } \\
\text { abrasion }\end{array}$ & $\begin{array}{c}\text { Excavation } \\
\text { in river }\end{array}$ \\
\hline
\end{tabular}

The granulometry of the left slope determined that the material is composed of well-graded sand with some silt, and, for the right slope, it is a mixture of poorly graded gravel with a considerable percentage of coarse sand. Similarly, the excavation sample was carried out, consisting of coarse gravel with a low percentage of fines (ratio $80 \%$ coarse and $20 \%$ fine). The results obtained for Atterberg limit tests to determine the soils' plasticity, detailed in Table 2 .

Table 2. Results of the Atterberg limits tests for slopes

\begin{tabular}{c|c|c}
\hline Tests & Left slope & Right slope \\
\hline Liquid limit & 38.70 & 62.40 \\
\hline Plastic limit & 31.20 & 43.73 \\
\hline Plasticity index & 7.40 & 18.31 \\
\hline
\end{tabular}

From the triaxial, cohesion and internal friction angle were obtained, both for the left slope and the right slope, as shown in Table 3. From the Los Angeles abrasion test, it was obtained that the wear percentage is $32.82 \%$. As an additional test, the concrete specimens were elaborated, from which it was obtained that the concrete made with coarse aggregate obtained a resistance of $277.8 \mathrm{Kg} / \mathrm{cm}^{2}$.

Table 3. Results of the triaxial tests

\begin{tabular}{c|c|c}
\hline Tests & Left slope & Right slope \\
\hline Cohesion & $54.92 \mathrm{kPa}$ & $348.07 \mathrm{kPa}$ \\
\hline Internal friction angle & $37.23^{\circ}$ & $20.30^{\circ}$ \\
\hline
\end{tabular}

\subsection{Design of the technical-artisanal dike}

The dike (tape) design was made based on the results obtained, considering the characteristics established below:

(1) The dike must be made up of a very well compacted gravel-sandy embankment with an average diameter of 1", which may consist of the material found in the river.

(2) The embankment must have a trapezoidal section, with a base greater than $7.00 \mathrm{~m}$, a baseless than $2.00 \mathrm{~m}$ and a height of $2.50 \mathrm{~m}$.

(3) The embankment must be covered by a reinforced concrete covering f'c $=360 \mathrm{Kg} / \mathrm{cm}^{2}$, a thickness of $\mathrm{e}=0.50 \mathrm{~m}$. The coarse aggregate used to make this concrete can be obtained from the material found in the riverbed.

(4) The concrete finish must be perfectly smooth.

(5) A ridge $0.50 \mathrm{~m}$ thick and $1.00 \mathrm{~m}$ high will be formed by burying the concrete in the natural terrain.

(6) The concrete must contain an electro-welded mesh of $20 \times 20 \mathrm{~cm}$, Ø $8 \mathrm{~mm}$, leaving $5 \mathrm{~cm}$ of covering on each side.

(7) To guarantee the dike's stability, the embedments must be inserted $7 \mathrm{~m}$ on each edge of the river, thus avoiding any possibility of erosion on the dike's sides.

(8) After the dike's embedments have been built, the channel's edges must be rebuilt, using a mixture of clay soilType I Portland cement with a 3:1 ratio.

(9) The soil must be compacted in layers of $0.25 \mathrm{~m}$ at $95 \%$ of the standard Proctor in the upper part.

The dike design (Figure 5) was carried out based on the results obtained, considering the characteristics established below. Considering the characteristics and construction guidelines given above, the civil works' total cost is estimated at USD 94,662.53. 96\% represents the dike structure's construction (Concrete f'c $=360 \mathrm{Kg} / \mathrm{cm}^{2}$ and electro-welded mesh $20 \times 20$, $\varnothing 8 \mathrm{~mm}$ ), and the rest represents the cost of earthworks. 


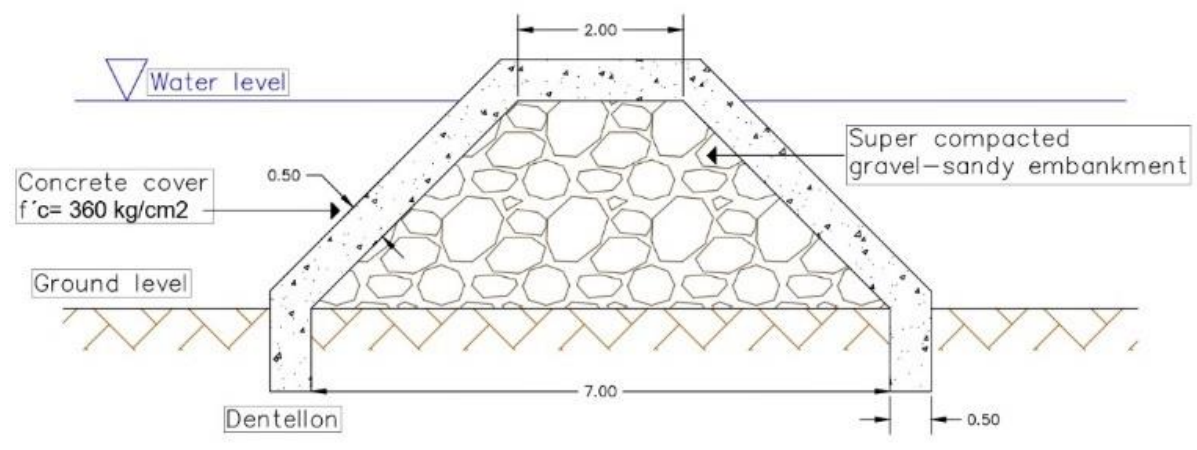

Figure 5. A cross-sectional view of the dike. (Source: [41])

\section{ANALYSIS OF RESULTS}

The study site's choice is considered the most optimal because it is located near two wells owned and managed by JAAPMAN (well 1 and 2 in Figure 3). This would be beneficial, thanks to the accumulation of water in that sector of the river, which would generate the aquifer's recharge used to supply Manglaralto [2, 26]. Thanks to the study sector's digitised model (Figures 4 and 5), the tape's excellent location was verified; since there would be a large reservoir and a narrow area, which minimises the work's cost maximises storage. For the construction of the dike, an embedment of not less than $5 \mathrm{~m}$ was established because, from the granulometric tests, it was possible to determine that the slopes on which the structure is based consist of materials not suitable for embedment since the slope the left consists of fine sand and the right consists of fine gravel.

Thanks to the Los Angeles abrasion and compression resistance tests, it was obtained that the material can be used as an aggregate for the concrete that will line the dike since the maximum allowable wear is $40 \%$ according to the ASTM C131 standard. and ASTM A535 [42]. Also, it reaches the permitted resistance range $\left( \pm 10 \mathrm{Kg} / \mathrm{cm}^{2}\right)$, directly benefiting the referential budget for civil works. For the construction of the dike, although in the laboratory tests, the concrete has been dosed to obtain a resistance f' $\mathrm{c}=280 \mathrm{Kg} / \mathrm{cm}^{2}$, which, to design the structure is efficient, it is recommended that the resistance of the concrete let $\mathrm{f}^{\prime} \mathrm{c}=360 \mathrm{Kg} / \mathrm{cm}^{2}$. This in order to increase its resistance against water erosion and to be able to resist the blow of blocks that may impact the structure, in addition to the fact that the concrete finish must be perfectly smooth, in such a way that it facilitates the flow of water together with the materials that this drag.

Carrión et al. [26], you can see the benefits that the construction of this reinforced concrete dam design has brought. A case similar to that of Manglaralto, in which dikes were built to artificially recharge the aquifers to supply the populations of sectors where access to water is problematic, is that of the hydrological correction dam of the Quípar River located in Spain. Located in a semi-arid region where surface water resources are scarce; in this case, there are other dams in Spain, as in the country dams have been built to retain water to recharge the associated aquifers since the end of the 20th century [43]. The artificial recharge of aquifers is a subject that has been widely studied and treated in several countries such as Libya, Algeria, Egypt, Sudan, Portugal, Spain, Greece, Germany, Finland, among others. This requires artificial techniques such as the construction of dams to be able to solve its hydrological deficit and in this way obtain indirect benefits such as reducing poverty, reducing health risks, increasing people's standard of living and, among other benefits, increasing the sustainability of the place.

The aquifers receive direct benefits thanks to the construction of dikes, and in the case of Manglaralto, this dam not only helps to retain surface water and increase the amount of groundwater but also prevents the salinity that affects the material of the subsoil [27] contaminates the well due to its location near the sea. In addition to this, the Manglaralto aquifer is considered by Herrera et al. [44, 45] a site of geological interest, so by allowing its recharge, it is giving way to its conservation and preservation.

The advantages obtained due to the dike's construction are economic, social, environmental and cultural. In the economic aspect, the use of river aggregates is highlighted to reduce the cost of construction. In addition, thanks to the formed reservoir, the community practices fishing and tourism. In the social aspect, it can be noted that this reservoir area generates a recreation area for the community and tourists. In the environmental aspect, this reservoir allows the growth of the area's biodiversity and its surroundings. Furthermore, in the cultural aspect, the ancestral knowledge of the community is rescued. Previously, so that the river water does not escape into the sea, tapes (accumulation of soil in a part of the river) were made. This impact is being replicated in the communities near Manglaralto, such as Olón [4], Cadeate [6, 46] and Libertador Bolívar [47]. In these communities, engineering studies are being carried out in the basins to see the feasibility of constructing dikes.

\section{CONCLUSIONS}

The technical-artisanal dike (tape) was designed to allow optimal surface storage and artificial recharge of the aquifer to provide safe water to the Manglaralto community. This dike's dimensions are a total length of $30 \mathrm{~m}$ (16 m free length and 7 $\mathrm{m}$ embedment) and a height of $3 \mathrm{~m}$ (from the ground level to the covering). It has a reinforced concrete covering $0.5 \mathrm{~m}$ thick with a resistance of $360 \mathrm{Kg} / \mathrm{cm}^{2}$. A dentil of $0.5 \mathrm{~m}$ thick and 1 $\mathrm{m}$ high, an electro-welded mesh of $20 \times 20 \mathrm{~cm}$, Ǿ $8 \mathrm{~mm}$, a $3: 1$ soil-cement mixture for the reconstruction of the river edges and compaction of $95 \%$ of the standard Proctor in the upper part of the embedments.

The designed structure will allow the overflow of streams in the ample avenues while achieving impoundment and retention of the subsurface flow in the alluvial deposit

The referential budget for civil works is USD 94,662.53, which $96 \%$ represents the structure of the dike, and the rest is 
earth movement. An opportunity for the dike's construction is that the cost per earth movement for the work is considerably reduced because the river's material can be used as an aggregate for the concrete.

After all the pertinent considerations exposed in this research, such as the social, economic and environmental impact, it can be said that the construction of the dam, as part of the solution to the problem of water scarcity of the Manglaralto Parish, is feasible.

\section{ACKNOWLEDGMENT}

To Manglaralto Regional Drinking Water Administration Board (JAAPMAN), to the Olón Regional Drinking Water Board (JRAPO), to the project of the Unit of Links with the Society (UVS-ESPOL) "Resilience in water management, in the face of COVID-19, Manglaralto", and, to the ESPOL research project "Registration of geological and mining heritage and its impact on the defence and preservation of geodiversity in Ecuador".

\section{REFERENCES}

[1] UNESCO-WWAP. Informe de las Naciones Unidas sobre el desarrollo de los recursos hídricos en el mundo. http://www.unesco.org/new/es/natural-

sciences/environment/water/wwap/wwdr/, accessed on May 20, 2021.

[2] Herrera Franco, G., Carrión Mero, P., Briones Bitar, J. (2019). Management practices for a sustainable community and its impact on development, ManglaraltoSanta elena, Ecuador. Proceedings of the Proceedings of the LACCEI international Multi-conference for Engineering, Education and Technology, Jamaica. http://dx.doi.org/10.18687/LACCEI2019.1.1.130

[3] Seckler, D., Barker, R., Amarasinghe, U. (1999). Water Scarcity in the twenty-first century. International Journal of Water Resources Development, 15(1-2): 29-42. https://doi.org/10.1080/07900629948916

[4] Herrrera-Franco, G., Bravo-Montero, L., Carrión-Mero, P., Morante-Carballo, F., Apolo-Masache, B. (2020). Community management of the Olon coastal aquifer, Ecuador, and its impact on the supply of water suitable for human consumption. WIT Transactions on Ecology and the Environment, 241: 169-181. https://doi.org/10.2495/SDP200141

[5] UN. The 17 SDG. https://sdgs.un.org/goals/, accessed on May. 19, 2021.

[6] Carrión-Mero, P., Morante-Carballo, F., ToalomboChimborazo, M., Mora-Villón, D., Briones-Bitar, J., Berrezueta, E. (2020). Groundwater exploration for a susutainable supply plan in a rural community: Case cadeate, Santa Elena, Ecuador. Proceedings of the Proceedings of the LACCEI international Multiconference for Engineering, Education and Technology, Vitual http://dx.doi.org/10.18687/LACCEI2020.1.1.294

[7] Carrión-Mero, P., Briones-Bitar, J., Macías-Núñez, E. (2020). Technical alternatives analysis for water supply in the rural parish of Limonal, Ecuador. WIT Transactions on Ecology and the Environment, 241: 183195. https://doi.org/10.2495/SDP200151
[8] Shiklomanov, I. (1993). Water in Crisis: A Guide to the World's Fresh Water Resources. Oxford University Press.

[9] Setegn, S.G., Rayner, D., Melesse, A.M., Dargahi, B., Srinivasan, R. (2011). Impact of climate change on the hydroclimatology of Lake Tana Basin, Ethiopia. Water Resources Research, 47(4). https://doi.org/10.1029/2010WR009248

[10] Herrera-Franco, G., Martos-Rosillo, S., Carrión-Mero, P. Morante-Carballo, F., Briones-Bitar, J., Durán, A., Vélez-Upegui, J., Castro-Lucic, M., Mateos, L., Bardales, J.D., Peña, F., Gutiérrez-Ojeda, C. (2020). Water Sowing and Harvesting (SyCA), ancestral techniques that solve problems of the XXI century. Proceedings of the Proceedings of the LACCEI international Multiconference for Engineering, Education and Technology, Vitual Edition. http://dx.doi.org/10.18687/LACCEI2020.1.1.299

[11] Boeri, A., Longo, D., Gianfrate, V., Lorenzo, V. (2017). Resilient communities. Social infrastructures for sustainable growth of urban areas. A Case Study. Water Resources Research, 12(2): 227-237. https://doi.org/10.2495/SDP-V12-N2-227-237

[12] FAO. El crecimiento económico es necesario, pero no suficiente para acelerar la reducción del hambre y la malnutrición.

http://www.fao.org/publications/sofi/2012/es/, accessed on Jan. 18, 2021.

[13] Agudelo, R. (2005). El agua, recurso estratégico del siglo XXI. Revista Facultad Nacional de Salud Pública, 22(1): 91-102

[14] Oki, T., Agata, Y., Kanae, S., Saruhashi, T., Yang, D., Musiake, K. (2001). Global assessment of current water resources using total runoff integrating pathways. Hydrological Sciences Journal, 46(6): 983-995. https://doi.org/10.1080/02626660109492890

[15] Rijsberman, F.R. (2006). Water scarcity: Fact or fiction? Agricultural Water Management, 10(1-3): 5-22. https://doi.org/10.1016/j.agwat.2005.07.001

[16] Odeh, T., Mohammad, A.H. (2020). Wise water resources management under the increasing number of refugees in the third poorest water resources country (Jordan) - a suggested future spatial plan for water resources investments. International Journal of Sustainable Development and Planning, 15(2): 235-238. https://doi.org/10.18280/ijsdp.150214

[17] Alcamo, J., Flörke, M., Märker, M. (2007). Future longterm changes in global water resources driven by socioeconomic and climatic changes. Hydrological Sciences Journal, $52(2)$ : https://doi.org/10.1623/hysj.52.2.247

[18] Herrera-Franco, G., Carrión-Mero, P., Aguilar-Aguilar, M., Morante-Carballo, F., Jaya-Montalvo, M., MorilloBalsera, M.C. (2020). Groundwater resilience assessment in a communal coastal aquifer system. The Case of Manglaralto in Santa Elena, Ecuador. Sustainability, $12(19)$ : $\quad 8290$. https://doi.org/10.3390/su12198290

[19] Sixt, G., Klerkx, L., Griffin, T. (2018). Transitions in water harvesting practices in Jordan's rainfed agricultural systems: Systemic problems and blocking mechanisms in an emerging technological innovation system. Environmental Science \& Policy, 84(1): 235-249. https://doi.org/10.1016/j.envsci.2017.08.010

[20] Chica, D., Reyes, C. (2011). Diseño e implementación 
del plan de reestrucción turística en la cabecera parroquial Manglaralto de la provincia de Santa Elena de la costa ecuatoriana. Guayaquil, Ecuador. Ing. dissertation. ESPOL Polytechnic University, Guayaquil, Guayas, Ecuador.

[21] INEC-Ecuador. Agua, saneamiento e higiene: medición de los ODS en Ecuador. https://www.ecuadorencifras.gob.ec/indicadores-odsagua-saneamiento-e-higiene/, accessed on Jan. 18, 2021.

[22] SENPLADES-Ecuador. Agua potable y alcantarillado para erradicar la pobreza en el Ecuador. https://www.planificacion.gob.ec/wp-

content/uploads/downloads/2014/09/FOLLETO-Agua-

SENPLADES.pdf, accessed on May. 19, 2021.

[23] Morante-Carballo, F., Marcatoma-Brito, L., CarriónMero, P., Aguilar-Aguilar, M., Tumbaco-Ramírez, J. (2019). Urban wastewater treatment through a system of green filters in the Montañita commune, Santa elena, Ecuador WIT Transactions on Ecology and the Environment, 239: 233-249. https://doi.org/10.2495/WS190211

[24] Herrera-Franco, G., Alvarado-Macancela, N., GavínQuinchuela, T., Carrión-Mero, P. (2018). Participatory socio-ecological system: Manglaralto-Santa Elena, Ecuador. Geology, Ecology, and Landscapes, 2(4): 303310. https://doi.org/10.1080/24749508.2018.1481632

[25] Borbor, A., Vera, J. (2014). Estudio para la Optimización de la Distribución de Agua para Consumo Humano, por parte de la Junta Regional de Manglaralto, Santa Elena, Ecuador, Ing. dissertation. ESPOL Polytechnic University, Guayaquil, Guayas, Ecuador.

[26] Carrión, P., Herrera, G., Briones, J., Sánchez, C., Limón, J. (2018). Practical adaptations of ancestral knowledge for groundwater artificial recharge management of Manglaralto coastal aquifer, Ecuador. WIT Transactions on Ecology and the Environment, 217: 375-386. https://doi.org/10.2495/SDP180341

[27] Morante-Carballo, F., Montalván, F.J., Carrión-Mero, P., Herrera-Franco, G., Heredia, J., Elorza, F.J., Pilco, D., Solórzano, J. (2019). Hydrochemical and geological correlation to establish the groundwater salinity of the coastal aquifer of the Manglaralto River basin, Ecuador. WIT Transactions on Ecology and the Environment, 229: 139-149. https://doi.org/10.2495/WRM190141

[28] Hernández-Peñaloza, N., Zizumbo-Villarreal, L., Torregrosa-Martí, T. (2017). Agua y turismo como instrumentos de acumulación de capital, el caso de Benidorm, España. Teoría y Praxis, 21: 31-53. https://doi.org/10.22403/UQROOMX/TYP21/02

[29] CONVOCA. Miraflores, la comunidad rural de lima que utiliza diques ancestrales para conservar el agua. https://convoca.pe/agenda-propia/miraflores-lacomunidad-rural-de-lima-que-utiliza-diquesancestrales-para-conservar, accessed on Jan. 18, 2021.

[30] Herrera, G., Carrión, P., Yambay, K., Briones, J. (2019). Educational considerations for conservation management and sustainable development of a watershed. Manglaralto, Santa Elena-Ecuador. Proceedings of the INTED2019, Valencia, España, IATED2019. http://doi.org/10.21125/inted.2019.2291

[31] Herrera, G., Yambay, K., Carrión, P. (2018). Participatory action research as an integrating factor in research projects-the educational process of the inhabitants of Manglaralto coastal aquifer in Ecuador.
Proceedings of the ICERI2018, Sevilla, España, IATED2018. http://doi.org/10.21125/iceri.2018.2235

[32] Campoverde, J., Fajardo, I. (2019). Contribución de la Geología Aplicada para la Mejora en el Diseño de un Dique en la Subcuenca del río Manglaralto, Provincia de Santa Elena, Ing. dissertation. ESPOL Polytechnic University, Guayaquil, Guayas, Ecuador.

[33] SNI. Archivos de Información Geográfica. https://sni.gob.ec/coberturas, accessed on Jan. 18, 2021.

[34] Machiels, L., Garcés, D., Snellings, R., Vilema, W., Morante, F., Paredes, C. and Elsen, J. (2014). Zeolite occurrence and genesis in the Late-Cretaceous Cayo arc of Coastal Ecuador: Evidence for zeolite formation in cooling marine pyroclastic flow deposits. Applied Clay Science, $\quad 87(1)$ : 108-119. https://doi.org/10.1016/j.clay.2013.10.018

[35] Amado, J. (1990). Estudio Hidrogeológico De La Cuenca Baja Del Río Manglaralto Provincia Del Guayas, Ing. dissertation. ESPOL Polytechnic University, Guayaquil, Guayas, Ecuador.

[36] Carrión-Mero, P., Morante-Carballo, F., Varas, M., Herrera-Franco, G., Briones-Bitar, J., MalavéHernández, J., Fajardo-González, I., CampoverdeCabrera, J. (2020). Applied geology to the design of handcrafted dikes (tapes) and its impact in the recharge of the manglaralto coastal aquifer, Santa Elena, Ecuador. Proceedings of the Proceedings of the LACCEI international Multi-conference for Engineering, Education and Technology, Vitual Edition. http://dx.doi.org/10.18687/LACCEI2020.1.1.307

[37] Núñez del Arco, E. (2003). Geología del Ecuador. ESPOL Polytechnic University.

[38] INAMHI. Anuario Meteorológico 2013. http://www.serviciometeorologico.gob.ec/docum_instit ucion/anuarios/meteorologicos/Am_2013.pdf*, accessed on Jan. 18, 2021.

[39] ASTM. ASTM https://kupdf.net/download/astm-c-136-01doc_58a6102b6454a7d10db1e8eb_pdf, accessed on Jan. $18,2021$.

[40] ASTM. ASTM D4318-95a: Standard Test Method for Liquid Limit, and Plasticity Index of Soils. https://ensayosdelaboratoriosuelos.files.wordpress.com/ 2015/12/traduccic3b3n-astm-d4318.pdf, accessed on Jan. $18,2021$.

[41] Herrera, P. (2018). Análisis de la Construcción de un Dique como Solución para el Problema de Abastecimiento de Agua de la Parroquia Manglaralto. ESPOL Polytechnic University, Guayaquil, Guayas, Ecuador.

[42] ASTM. ASTM A535-85: Specification for SpecialQuality Ball and Roller Bearing Steel. https://www.aenor.com/normas-y-libros/buscador-denormas/astm?c=040449, accessed on Jan. 18, 2021.

[43] Rodríguez, T., Martínez, M., Romero, A. (2006). Utilización de diques de corrección hidrológica ya existentes para recarga de acuíferos y propuesta de otros nuevos en la cuenca del río Quipar (Sureste de España). In: López, J., Fernández, R., Ramos, G. (eds) Las aguas subterráneas en los países mediterráneos. IGME, España.

[44] Herrera, G., Carrión, P., Briones, J. (2018). Geotourism potential in the context of the Geopark project for the development of Santa Elena province, Ecuador. WIT Transactions on Ecology and the Environment, 217: 557- 
568. https://doi.org/10.2495/SDP180481

[45] Herrera-Franco, G., Carrión-Mero, P., Alvarado, N., Morante-Carballo, F., Maldonado, A., Caldevilla, P., Briones-Bitar, J., Berrezueta, E. (2020). Geosites and Georesources to Foster Geotourism in Communities: Case Study of the Santa Elena Peninsula Geopark Project in Ecuador. Sustainability, 12(11): 4484. https://doi.org/10.3390/su12114484

[46] Velasco, R., Moreira, S. (2021). Diseño de dique para embalsar y lograr la recarga subterránea en el valle Cadeate y diseño de un embalse tipo para una finca. ESPOL Polytechnic University, Guayaquil, Guayas, Ecuador.

[47] Rivera, G. (2019). Diseño de dique para embalsamiento de agua dulce en la comuna Libertador Bolívar, provincia de Santa Elena. ESPOL Polytechnic University, Guayaquil, Guayas, Ecuador.

\section{NOMENCLATURE}

$"$

Ø $\quad$ Steel diameters

ASTM American Society for Testing and Materials

$\mathrm{cm} \quad$ Centimeter

$\mathrm{cm}^{2} \quad$ Square centimeter

e.g. $\quad$ Exempli gratia

f'c Concrete Compressive strength

GPS Global Positioning System

$\mathrm{kg} \quad$ kilogram

$\mathrm{km}^{2} \quad$ Square kilometers

$\mathrm{m} \quad$ Meters

$\mathrm{m}^{3} \quad$ Cubic meters

$\mathrm{mm} \quad$ Millimeters

USD United States Dollar

UTM Universal Transverse Mercator 